\title{
The prospect of humanising development discourse in Africa through Christian anthropology
}

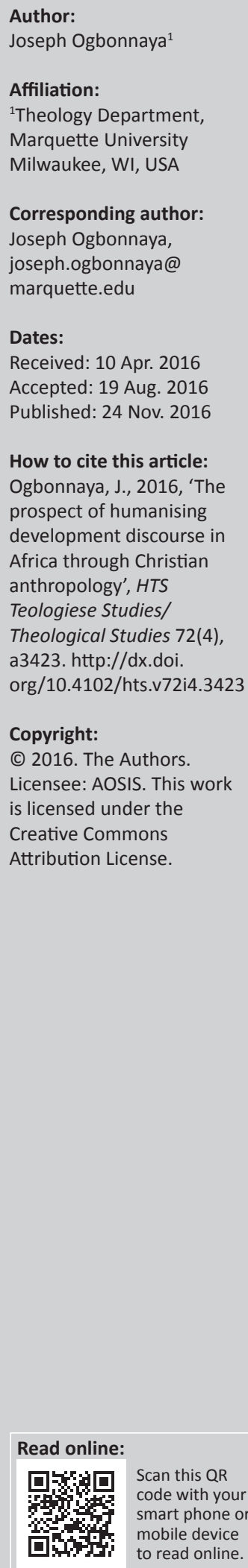

\begin{abstract}
The invention of development as public discourse began with US President Truman's 1949 speech that trumped up an illusion of global material prosperity based on a total restructuring of the 'developing' world on the model of development and material achievement of the West. Truman argued that this painful process was the only recipe for world prosperity. After decades of serious engagement on development discourse and multiple implementations of successive theories, the situation of the developing countries has not improved as rapidly as expected. At the same time, the developed countries are experiencing various forms of financial crises. This article acknowledges the professionalisation of development discourse, and proposes humanising development discourse in Africa in the light of Christian anthropology. This vision of integral development promotes the common good on the basis of God's love and respect for the uniqueness of the human person.
\end{abstract}

\section{Introduction}

Try searching the dictionary for the word 'development' and you will find an uncontroverted plethora of meanings. But these meanings become blurred when 'development' is used in relation to such concepts as material wellbeing, progress, social justice, economic growth, personal blossoming, or even ecological equilibrium. As will become clear in a later section of this article, the cacophony of meanings of 'development' arises from the Western dualistic worldview, which has the tendency of separating the material and the spiritual (metaphysical) worlds as well as emphasising individualism and competition often to the detriment of the common good. This is opposed to the position of the more integral African worldview where the material world is linked to the spiritual, and progress is connected to the common good. The African concept of Ubuntu expressed in the communitarian societal value of universal belongingness to the human community expresses the concept of 'development' more broadly.

Consequent upon differences in understanding, and on account of a variety of sociological and political changes, the meaning associated with the word 'development' differs depending on the hemisphere articulating the definition. For instance, in the Northern hemisphere, development refers to meeting the needs of economies considered less advanced according to Northern standards. We see this in Paul A. Haslam's edited volume Introduction to International Development (2009: 5), which replaces President Truman's 'Four Point Speech', classification of First, Second, and Third World countries, and instead uses the labels 'developed' and 'developing' to denote countries' levels of wealth or poverty. The rich industrialised countries of the Northern hemisphere are 'developed'; the poor pre-colonial countries of the world are 'developing'.

The binary conceptual differentiation of development is the result of the acceptance of the enlightenment idea of infinite progress supposedly impeded only by the power of superstition, despotism and war. The triumph of social evolutionism in the 19th century took this idea to a new level equating progress with history and assuming that all nations travel the same road, following the lead of the West to development owing to the size of its production; the use of reason and scientific and technological advancement. Thus, other cultures and peoples were deprived of their histories and specificities. They were seen in comparison with the West and are expected to be like the West. As Gilbert Rist (2002) asserts:

What passes today for the truth of the history of humankind (that is, progressive access of every nation to the benefits of 'development') is actually based upon the way in which Western society - to the exclusion of all others - has conceptualised its relationship to the past and the future. (p. 44; original italics)

Note: This article forms part of the special collection on 'Engaging development: Contributions to a critical theological and religious debate' in HTS Teologiese Studies/Theological Studies Volume 72, Issue 4, 2016. 
Thus, following Rist, we could speak of a solidified system of thought, the making of a world system resulting from the European or Western practices of extending their hegemony over other peoples and cultures based on their convictions of 'development' from above. This initially took the form of colonisation when countries like France, Britain, Germany and Belgium had territories in Africa, India, the Middle East, and so on. In turn the postcolonial development programme gradually began to take shape after the pattern of the US' 1947 Marshall Plan to rebuild war-torn Europe, devastated by World War II. The desire of the other continents to be rescued in the same manner cemented the modern idea of development as economic growth. President Truman's Point Four programme (1949) extended technical assistance to Latin America and to the poorer countries of the world, inaugurating the development age. With the use of the word underdeveloped areas in Point Four, development took on a transitive meaning, (an action performed by an agent upon another) as a principle of social organisation (Harry 1949). ${ }^{1}$

This article utilises the various development theories across decades to analyse the dominant development paradigm, especially the neoliberal economic globalisation theory. Therefore, I will take as for granted, conventional theories of development: classical and neoclassical economics to Keynesian economics ranging from development as modernisation to neoliberal economics. In the process I will not concern myself with nonconventional, critical theories of development, such as Marxism, socialism and development, poststructuralism, postcolonialism and postdevelopmentalism or with feminist theories of development or Critical Modernism. It is not because I do not think these theories are important; rather, I recognise, appreciate and draw upon the work already done in these areas by various disciplines (see Richard Peet \& Elaine Hartwick 2009). Thus, the focus of this article is confined to a critical analysis of the hegemonic form of development as economic globalisation in the light of the age-old challenge of income inequality responsible for these theories of development in the first place. Relying on the works of some development economists like Thomas Piketty (2014), the first part of the article critiques the exercise of power in development discourse. The second part proposes, in the light of Christian anthropology and the African concept of Ubuntu, a humanisation of development that would properly focus on the well-being of the human person whose dignity is inherent in human beings believed to be created in the image and likeness of God.

\section{Economic globalisation in the 21st century}

Appraisal of the impacts of neoliberal economics or economic globalisation on any population has often resulted in conspiracy theories, blame games and needless antagonism especially as these assessments are often unsubstantiated

1.Part of President Truman's Point 4 Program states: 'We must embark on a bold new program for making the benefits of our scientific advances and industrial progress available for the improvement and growth of underdeveloped areas'. and generally theoretical, at times exhibiting crass ignorance of the dynamics of wealth distribution and income inequality. Having said this, one must not ignore or sidestep the importance of balance (which is difficult to attain) between capital and labour. Unresolved, this breeds conflict and in some cases deadly violence resulting to loss of lives. Thomas Piketty's Capital in the twenty-first century (2014) deals squarely with this problem of income inequality, which has plagued societies of every age. This problem is important in the 21st century because development discourse is equally about the justice expected in the relation between income and labour that often contributes to inequalities.

It is clear that the invisible hand of the market only benefits societies that already possess wealth, and this is often drawn at the back of other countries and continents. The ongoing dominance of such countries and continents over others depends upon persistent political manoeuvres by the dominant groups. The reality is that poor countries (especially in Africa) continue to experience great capital outflows, because rich countries own the majority of their industrial output and financial market. Piketty (2004:68-69) estimates 'that the foreign-owned share of Africa's manufacturing capital may exceed $40 \%-50 \%$ and may be higher in other sectors. Despite the fact that there are many imperfections in the balance of payments data, foreign ownership is clearly an important reality in Africa today'. It is often repeated that African countries must increase their FDI (Foreign Direct Investment) in order to increase the foreign currency to boost their economies, to increase their per capita income per head. The truth of the matter is that poor countries keep on enriching foreign countries, as most of these foreign countries manage most of the resources of African countries. However, in other emerging economies, which finance their investments, and do not depend on foreign direct deposits, the reverse is the case. Piketty (2014) asserts:

Furthermore, if we look at the historical record, it does not appear that capital mobility has been the primary factor promoting convergence of rich and poor nations. None of the Asian countries that have moved closer to the developed countries of the West in recent years has benefited from large foreign investments, whether it be Japan, South Korea, or Taiwan and more recently China. In essence, all of these countries themselves financed the necessary investments in physical capital and, even more, in human capital, which the latest research holds to be the key to long-term growth. Conversely countries owned by other countries, whether in the colonial period or in Africa today, have been less successful, most notably because they have tended to specialise in areas without much prospect of future development and because they have been subject to chronic political instability. (p. 70)

Africa's involvement in economic liberalisation must be in such a way that it benefits from open markets just as Asians benefit from the free movements of goods and services. Africa's economy will never improve as long as it remains hinged on dependence on foreign capital.

The failure of the modernisation idea of development is increasing the poverty of the poor and the wealth of 
the wealthy. Unfortunately, this appears to be the strategy of neoliberal economics, which prioritises the market above the human person. Thus there is the glorification of capital over human well-being. In spite of the arguments in defence of it, in practice, neoliberalism contains systemic injustice within its structures. Perhaps this arises from its aiming primarily for profit and economic growth. The various contributors in a book on neoliberalism (Braedley \& Luxton 2010:6) agree, 'neoliberalism is not advancing social justice and equality, but is, instead, reinscribing, intensifying, and creating injustices and inequality'. Indeed it cannot advance social justice because its major value - the promotion of individual freedom through competition in the market that creates wealth - fails to account for differences in the starting point of competition, opportunities available for equal competition or extenuating circumstances such as unequal treatment because of race and sex (gender regimes, ethnicity and racism) and even health issues that will make one unable to effectively compete. It also does not attend to how choices by policy makers constrain the choices of other people and poor countries' participation in the market. Furthermore, markets do not work as well as market economic theories presume. There is no level playing ground between the rich and the poor, or the employer and the employee; neither is there between resource-rich but less powerful nations and those industrialised, and more technologised societies that enjoy more international political clout.

Joseph E. Stiglitz, the Nobel Prize laureate in Economics, and a staunch believer in the prospect of economic globalisation to increase human prosperity and lift the poor from destitution, advocates radical change in the economic policies imposed on developing countries. Stiglitz (2002:x) denounces policies based more on 'ideology and politics', which result in 'wrong-headed actions, ones that did not solve the problem at hand but that fit with the interests or beliefs of the people in power'. As an insider, Stiglitz exposes not only the lack of transparency of the institutions charged with providing policies for neoliberal reforms in developing countries, but also how the ideologies of the International Monetary Fund, the World Bank and the World Trade Organisation perpetuate the political and economic hegemony of the rich and developed countries with little consideration for the poor developing countries of the world. The IMF imposed Structural Adjustment Programme offers an important example. Stiglitz (2002) postulates:

IMF structural adjustment policies ... led to hunger and riots in many countries; and even when results were not so dire, even when they managed to eke out some growth for a while, often the benefits were disproportionately to the better-off, with those at the bottom sometimes facing even greater poverty ... But while no one was happy about the suffering that often accompanied the IMF programs, inside the IMF it was simply assumed that whatever suffering occurred was a necessary part of the pain countries had to experience on the way to becoming a successful market economy, and that their treasuries would, in fact, reduce the pain the countries would have to face in the long run. (p. xiv)

One calls to mind as well 'the shock doctrine' propounded by advocates of neoliberal capitalism which advises leaders to capitalise on disasters (either natural or orchestrated by allied governmental institutions) to impose economic, political and social changes people would not have accepted under normal circumstances (Chomsky 1999; Klein 2008). As Philip McMichael (2008) observes:

at the turn of the 21st century, the United Nations reported that the richest $20 \%$ of the world's population enjoyed 30 times the income of the poorest 20\% in 1960, but by 1997 the difference was of the order of 74. (p. 191)

Thus, it is not surprising that the World Trade Organisation (WTO) meetings draw public outcry such as the famous antiglobalisation protests during the WTO Seattle Ministerial (1999) conference. The failure of neoliberalism to fulfil its promises necessitates the constant need to trumpet its successes and achievements in reducing poverty and hunger; and supports the tendency of the United Nations to manufacture new development goals. It is not out of place to wonder whether Sustainable Development Goals will achieve what the Millennium Development Goals failed to achieve: its halving poverty by 2015.

Piketty $(2014: 431,437)$ does not think global inequality of wealth will be any different in the 21st century than in the previous century. In actual fact, the inegalitarian process of wealth distribution may take on unprecedented proportions in the new global economy. Unequal returns on capital widen the rich-poor divide within nations, and this is often complemented by unequal wealth between nations because the poor will always have less capital to invest than the rich and the wealthy. As global wealth increases, average income does not increase. For this reason, Piketty (2014:435) argues, 'the largest fortunes grew much more rapidly than average wealth'. This does not mean poor countries cannot grow rich, but all things being equal, they will not catch up with rich developed countries. One must also take account of political, military and economic factors as responsible for global distribution of capital, because market forces alone are not the determinant of economic growth. Countries at the periphery, edged out of the policymaking process by the rich and powerful and must borrow capital in foreign currencies in order to participate in international free market economy, will always be at a disadvantage. Inept and corrupt leadership and other forms of internal political and social upheaval exacerbate these countries' situation. This is particularly the case in the African continent's striving for 'development'.

\section{Africa and the development discourse}

The paternalistic attitude toward Africa in international trade is a carryover of the social evolutionism fostered by colonial anthropologists that construed Africans ahistorically, as people at the lowest level of the human race. As Basil Davidson (1969:27) observes, Africans were first called 'the undeveloped peoples', before they were classified as underdeveloped peoples who need Western technology and assistance in forms of aid to rise up to civilisation, per 
Truman's Point Four Programme. This paternalistic discourse extends the perception of the Negro as less human, which justifies the commodification of Africans as articles of trade. ${ }^{2}$

Newly independent African countries worked zealously to catch up with the West via the various strategies of the development decades. At the Bandung conference (1955), ${ }^{3}$ they and other 'third world countries' sought to develop a common 'development' policy to integrate into the world economy. By 1960 the International Development Association was formed to grant loans on lower interest rates to developing countries with the purported aim of allowing them to benefit from the 1960s United Nations declared 'Development Decade'. Alongside most of Latin America, African countries adopted stages of development as contained in W.W. Rostow's modernisation theory of development. Africa borrowed heavily in order to attain technology transfer, buy equipment and machineries to revolutionise agriculture, build infrastructure, fund education, provide healthcare, construct cities, improve transportation, etc. It is now common knowledge that such loans, which were either embezzled or used for elephant projects to prop up military regimes in Africa, accumulated heavy interest. This forced Africa into the neoliberal economic system unprepared. Stephen Lewis's (2005) calculation of the African continent's debt and repayment gives a bird's eye view of Africa's predicament in its attempt to catch up with the West:

It may seem hard to believe, but between 1970 and 2002, Africa acquired $\$ 294$ billion of debt. Much of the debt was assumed by military dictators who profited beyond the dreams of avarice, and left for the people of their countries, the crushing burden of payment. Over the same period, it paid back $\$ 260$ mostly in interest. At the end of it all, Africa continued to owe upwards of $\$ 230$ billion in debt. Surely that is the definition of international economic obscenity. Here we have the poorest continent in the world paying off its debt, again and again, and forever being grotesquely in hock. ${ }^{4}$ (p. 22)

Indeed, the above-mentioned predicament sketched by Lewis betrays the lie of 'development'. Instead of enhancing the development of the poor countries, the 'project' of development benefited the rich and impoverished the poor countries. This is why third world countries agitated intensely for a fair share in development, an end to imperialism and extortion of the transnational corporations during the development decade of the 1970s. At the international level, this led to the demand for a New International Economic

\footnotetext{
2. On addition to the viciousness of the enslavement, American economy is built partly at the backs of forced slave labor. Piketty's analysis is instructive here: 'What one finds is that the total market value of slaves represented nearly a year and a half of US national income in the late 18th century and the first half of the 19th century, which is roughly equal to the total value of farmland' (Piketty 2014:159).

3. Bandung Conference is the Asian-African conference in Bandung, Indonesia convened by leaders of the Third World governments in 1955 to develop a common 'development' policy - integration into the world economy, peace and role especially that of non-alignment in the Cold War.

4. It is important to note here the successful role Christians played through the Jubilee Year Movement towards the eradication or reduction in some cases of most of African debt. It is sad as well to note that many African countries are once more pilling up mo it is sad as well to note that many African countries are once more pilling up more debts from international financial institutions partly due to vagarie of the international market but majorly due to corruption and mismanagement of their nation's resources (cf. Kim 2008:139-143).
}

Order (NIEO) to discuss, among other things, the issues of raw materials and development, and the inequality of the benefits of technological development that resulted in the widening gap between the rich and poor (Commission Française Justice et Paix 1978; International Documentation Center 1976; World Council of Churches 1975). ${ }^{5}$ Sadly, however, while this would have meant that the NIEO enshrine the rights of developing countries to the disposition of their own natural resources within international development law, every effort to do so has failed. Why? Margot E. Salomon (2013:31) offers a simple answer: 'industrialised countries as net beneficiaries of the global economic system would not allow it'. But is this not the presumed purpose of development - to replace the imperialism at the heart of exploitation for foreign profit, which President Truman's Point Four programme promised to stamp out? Should implementation of the Point Four program not have led to support for the NIEO and other policies to speed up the development of the 'underdeveloped' peoples? ${ }^{6}$

Instead, it turned out that the 'project' of development was rather designed to continuously benefit the dominant rich industrialised countries to make it easier for them to access the raw materials and to provide easy markets and consumers for their ever-expanding production powered by advanced technology. Benefits accruing to poor developing countries were often accidental: unintended consequences that arose from the self-interest of the dominant countries. It is little wonder then that the Lagos Plan of Action, an economic blueprint for the economic development of Africa (1980) by the Organisation of African Unity (now African Union) began in a tone of frustration with the whole 'project' of development they had formerly embraced with trust:

The effect of unfulfilled promises of global development strategies has been more sharply felt in Africa than in the other continents of the world. Indeed, rather than result in an improvement in the economic situation of the continent, successive strategies have made it stagnate and become more susceptible than other regions to the economic and social crises suffered by the industrialised countries. Thus, Africa is unable to point to any significant growth rate, or satisfactory index of general well-being, in the past 20 years. Faced with this situation, and determined to undertake measures for the basic restructuring of the economic base of our continent, we resolved to adopt a far-reaching regional approach based primarily on collective self-reliance. (Organisation of African Unity 1980:4)

The resolutions of the Lagos Plan of Action were approved by the Assembly of Heads of State and Government of the Organisation of African Unity (OAU) at its Second Extraordinary Session held from 28 to 29 April 1980, in Lagos, Nigeria. The Lagos Plan was constructed in the light of the NIEO agenda and aimed at self-reliance and greater

5.In spite of the massive support for NIEO, it was frustrated because the structural change it demands challenges the domination of the rich countries over the poor countries in international trade. Various Church organisations: World Council of churches, World Faith Organisations, Episcopal Conferences, theological associations, individual moralists, sociologists etc. wrote in support of NIEO.

6. In actual fact, the demise of the NIEO followed intense backyard activities by the United States to frustrate it (see Sharma 2013:572-604). 
participation of Africa in policies affecting them, especially their own economic development. Not surprisingly, the developed countries of the North vehemently opposed the resolutions taken because they advocated structural changes in the world politico-economic arrangement.

Instead, the IMF used the United Nations Economic Commission for Africa (1990) to impose an alternative programme: an austerity measure called the African Alternative Framework toStructural Adjustment Programmes for Socio-Economic Recovery and Transformation 1990 (AAFSAP). This is the infamous Structural Adjustment Programme that devastated Africa's social, economic, financial and political institutions in the 1990s. AAF-SAP aimed at a number of improvements in policy areas: '(1) financial management and efficiency of public enterprises and tighter financial accountability; (2) agricultural incentives; (3) export diversification; and (4) external debt management' (AAFSAP 1989). - Effectively, however, this programme once more served the interest of the international financial institutions. Instead of policies that sought Africa's self-reliance and selfdetermination in terms of control of their natural resources, as proponents of the NIEO advocated, this development regime preferred watered-down reports amenable to the interests of the countries of the rich North. One good example of this was the report of the South Commission, titled The Challenge to the South (1990). While focusing on South-South cooperation as well as North-South relations, it was instrumental in toning down the demands of the NIEO on structural change in the international economic order. Yet, because it devoted its attention to national development and on account of its stress on the responsibility of developing countries for their own development, the report was welcomed by spokespersons from the North (Nyerere 1993:xiii-xiv). As a result of this, African countries entered the global market ill equipped to compete and at a grossly disadvantaged position. The neocolonial Structural Adjustment Programmes, left them weakened politically, and destroyed them economically, financially, and socially. In addition, they were divided by ethnic rivalries, burdened by huge debts and left in disarray by greedy, corrupt leaders, and now were without the requisite skills, infrastructure and knowledge required to participate in technologically advanced global society.

It is no surprise then that sub-Saharan African nations do not feature among the countries making any significant growth towards convergence with the advanced economies in Piketty's analysis of economic growth, in spite of all the noises about economic growth in Africa. The growing economies projected by Piketty (2014:100) to converge with the Western economies include China and countries from Eastern Europe, South America, North Africa and the Middle East. This not only means that net foreign capital in subSaharan Africa is very low, it implies it is not growing compared to that of the other emerging economies. In fact, it is decreasing to such an extent that sub-Saharan Africa is doomed to remain the basket case of the world economy.
This view on sub-Saharan Africa's prospects as a region may have to be qualified in the light of the modest progress made in development and economic growth in various African countries. The annual regional report by the World Bank (2011:14) showcased continued growth in Africa thus stating: 'African countries south of the Sahara weathered the recent global economic crisis better than past crises, thanks in part to improved economic policies. As a result, Africa is one of the fastest-growing developing regions in the world'. And in turn the McKinsey Company Report (2010:1) titled 'Lions on the Move: The Progress and Potential of African Economies' by the McKinsey Global Institute corroborates the World Bank view of continued economic growth in African countries: 'Africa's collective GDP, at $\$ 1.6$ trillion in 2008, is now roughly equal to Brazil's or Russia's, and the continent is among the world's most rapidly growing economic regions. This acceleration is a sign of hard-earned progress and promise' (Leke et al. 2010). The Economist (J.O'S 2013) goes further by offering six countries as examples of the fastest-growing economies in the world:

Angola, Congo, Ethiopia, Lesotho, Malawi, Nigeria, Rwanda and Tanzania. All have enjoyed rapid growth in GDP per person. But they have also done well at translating that strong growth into improved well-being (in technical terms, the correlation between GDP per person and well-being above one in these countries). Income growth per person has been above $5 \%$ a year in Ghana, Mozambique and Uganda, too. But increases in wellbeing have not been quite as rapid as in the best performers. $(\text { J.O'S 2013) })^{7}$

Even though notable economic growth and improvements are recorded in some countries of sub-Saharan Africa, Jim Yong Kim and Christine Lagarde (2016:x) note that millions of Africans are still left out in spite of decades of embracing and implementing policies of various development decades including the now defunct Millennium Development Goals. (MDGs) Furthermore, this reported growth comes from resources and not commodities. Consequently, fluctuation in prices of these resources immediately affects the economies of these countries. The sustainability of the growth also depends upon how the countries invest the money they make during boom periods for their natural resources. For instance, the World Bank regional report on Africa for the 2015 fiscal year reveals the fluctuation in Africa's economic growth occasioned by vagaries in prices of goods:

Growth in Sub-Saharan Africa will slow to 4.1 percent in 2015, down from 4.5 percent in 2014 . The downturn largely reflects the decline in the prices of oil and other commodities. Growth will remain strong in most low-income countries, however, thanks to infrastructure investment and agriculture expansion, although lower commodity prices will dampen activity in countries that export metals and other key commodities.

7.The authors of articles in The Economist is often anonymous like the author j.o's. It believes what is written is more important than who authors are. This follows the ancient practice of pseudonyms of great works.

Other viewpoints point to the future of African growth and development in more Other viewpoints point to the future of African growth and development in more 'A recent report by the African Development Bank projected that, by 2030, much of Africa will attain lower-middle- and middle-class majorities, and that consume spending will explode from $\$ 680$ billion in 2008 to $\$ 2.2$ trillion. According to McKinsey and Co., Africa already has more middle class consumers than India, which has a larger population' (French 2012:5). 
Continued expansion of nonoil sectors, particularly services, is expected to lift growth in 2016 and beyond. Growth is expected to increase in lower-middle- and upper-middle-income countries, propelled by higher public investment and the recovery of tourism. (The World Bank 2015:1)

This confirms Morten Jerven's observation (2013:5): 'Gross Domestic Product (GDP) numbers tell us too little about what has really happened or about whether living conditions on the African continent are improving'. For example, the United Nations report on the Millennium Development Goals (2015:3) that led the transition to Sustainable Development Goals clearly articulate what I consider to be the weakness of the MDGs even though the report gave itself a pass mark: an inability to lift people out of poverty but instead increasing the poverty of the poor. Jim Young Kim and Christine Lagarde in The World Bank Global Monitoring Report (2015-2016) in this regard mentions the following three critical challenges:

A large percentage of the remaining poor are deeply poor, with income levels far below the poverty line... in many countries, the incomes of the bottom 40 percent declined, including in half of the high-income countries... Poverty reduction and shared prosperity are held back by unequal progress on the non-income dimensions of development, like access to essential services. (p. x)

So it is still correct to say that African economies are involved in market liberalisation while still stuck in the 18th century land-based European economic format. Its monetary policy resembles the pre-industrial rentier and mercantile economy, in which wealth is in the hands of a few landlords to whom the majority of citizens pay rent. In spite of abundant natural and human resources and capital accruing from these resources, its infrastructure is decrepit and unable to function in the service of commercial and financial global capitalism in the 21st century. For instance, the World Bank Group President, Jim Yong Kim, said in a speech presented at the Global Launch of 'Poverty in A Rising Africa' Report (2015) that 'only one in three people in sub-Saharan Africa has access to electricity and, when available, it can be unreliable and unaffordable'. The Executive Summary of African Poverty Report (2016:xv) claims extreme poverty is concentrated in sub-Saharan Africa: 'While pockets of ultrapoverty exist around the world, sub-Saharan Africa is home to most of the deeply poor'. Why does a continent that so faithfully followed the various development strategies continue to lag behind the rest of the technologically developed world?

\section{The politics of Africa's underdevelopment}

On account of poor leadership in Africa, a balanced assessment of underdevelopment in Africa must account for the phenomenon of corruption as well as the impact of social evolutionism that underlines the Western idea of development. I begin with the latter in view of the possible influence it may have had on the former.
African underdevelopment is traced to the triumph of 19th century social evolutionism, which advanced the idea of infinite progress for civilised peoples while perpetuating Africa's marginality. This theory classified a culture's creativity and intellectual achievements through a European cultural prism. It placed the black race at the lowest rung in the racial hierarchy. Accordingly, the inferior race was designed to be the slave of the rest of humanity. Colonisation perpetuated this social evolutionism not only by forcibly transforming Africa according to European constructs but also by distorting the orders of traditional society - the symbols of authority, and the understanding of and reverence for the sacred, its value structure - and replacing them with artificial consumption. This European superiority complex engendered an inferiority complex and timidity towards people of other races among African peoples. It promoted the idea that Africa is and cannot be creative; that it is marginal and can only depend on other nations to progress. Not least, this view of African people's inferiority was even extended to their creative arts, holding that despite their uniqueness they cannot be accepted as being original to them. V.Y. Mudimbe (1988) illustrates this Western epistemological ethnocentrism by stating that:

Since Africans could produce nothing of value; the technique of Yoruba statuary must have come from Egyptians; Benin art must be a Portuguese creation; the architectural achievement of Zimbabwe was due to Arab technicians; and Hausa and Buganda statecraft were inventions of white invaders. (p. 13)

The Western model of social transformation articulated in W.W. Rostow's (1991) ${ }^{8}$ modernisation theory of development (very influential during the colonial and postcolonial periods in Africa) advances social evolutionism. Development, Rostow argues, progresses by the gradual evolution of society from primitive to modernised mentality and technology. Africa's development is therefore predicated on its evolution from the state of primitivism to modernity, from being a-cultural to civilisation. In the process, Africa has to be guided by the technologically advanced societies of the West. Truman's designation of peoples as 'underdeveloped' in the Point Four programme speech thus aptly applies to Africa according to this construct. Rostow's development model was very influential in much of development policies in Africa in the 1960s, which were intended to make Africa like the West (Davidson 1992:199). Claude Ake (1996) illustrates this beautifully:

In the version of modernisation theory applied to Africa, such as W.W. Rustow's Stages of Economic Growth (1960), development replaces modernisation, the state of backwardness is regarded as pre-industrial, the movement to overcome it becomes the process of economic growth to be engineered by neoclassical tools, and the end of social evolution - that is, modernity - means industrialisation and high mass consumption. In the postwar period, when the development of the third world came into vogue, development thinking leaned more toward John Maynard

8. Rostow's modernisation theory is one of the prominent theories of development acknowledged at the beginning of this article. It is famous for its five stages . growth theory: the traditional society, the preconditions for take-off, the take-off the drive to maturity, and the age of high mass-consumption (see, Ogbonnaya 2013:Loc.199). 
Keynes than toward the classical tradition. By the late 1950s the orientations and assumptions of development thinking had become more structuralist. (p. 10)

In other words, Africa's prosperity is construed to lie in the hands of foreigners, and to be shaped according to their capital, expertise and ways of life. This, of course, implies that Africa must abandon its traditional cultural life as well as political, economic and social structures. To a large extent, Africa is underdeveloped the more it abandons its cultural life and traditional institutions.

But Africa is neither undeveloped nor underdeveloped. The pioneering works of scholars like Basil Davidson, Ali A. Mazrui, Cheikh Anta Diop, M. Angulu Onwuejeogwu and others, repeatedly debunk the lie of social evolutionism that excludes Africa from human civilisation. Africa is not only the cradle of civilisation, it is the birthplace of humankind. Africans have been able to inhabit and devise measures to survive in their often-harsh environment for thousands of years before the encounter with foreigners and before colonisation. Davidson (1969) rightly asserts in this regard:

\begin{abstract}
If one should praise 'the Greek spirit' as splendidly creative and inventive, one may perhaps express some admiration for an 'African spirit' which was far less favourably placed for the elaboration of the arts of life, but none the less made this continent supply the needs of man. Where, after all, lay the precedent for the social and ideological structures built by the Africans, so various and resilient, so intricately held together, so much a skillful interweaving of the possible and the desirable? Where did these systems draw their sap and vigour except from populations who evolved them out of their own creativeness? Even allowing for the distant precedents of Egypt, the peoples who settled Africa had surely less to go upon than the ancestors of Pericles. The balance needs adjusting here. (p. 37)
\end{abstract}

The prelude to Africa's development is reorientation of the African mind from the social evolutionistic ideas internalised in much of Africa. The entire construct of the project and paradigm of development is based upon the supposition that there exist undeveloped and underdeveloped peoples. These are peoples without history whose progress depends on the paternalism of other nations. This idea must be exposed for what it is - a blatant lie. Africa needs to overcome the inferiority complex ingrained in its peoples by the misrule of colonialism, neocolonialism, statism and manipulations of African elitist bureaucracy that corrupts the entire political structure and complicates the artificiality of Africa's nations.

The problem with Africa is no longer simply external but also internal. The insensitivity and greed of African leaders and politicians cannot be explained merely in terms of colonialism and imbalanced economic regimes. There is something else really wrong with several of the past and present leaders. We cannot sidestep this narrative in explaining Africa's underdevelopment. Walter Rodney (1972) aptly eulogises how Europe underdeveloped Africa. Perhaps, it is important to add to the equation: How Africans underdeveloped Africa! This enormity of corruption in
Africa warrants multiple articles beyond this one, but suffice it to say that corruption is so endemic in Africa that in Nigeria (the continent's largest oil producer), 'previous rulers stole some 3\% of the country's GDP every year' (World Economic Forum 2016). Those billions of dollars could have gone toward needed infrastructures for development. Corruption cuts across almost every aspect of societal life: political, civil, economic, and even religious. It is so bad that public officials, law enforcement agents, judges, health care professionals, civil servants, etc., demand bribes for them to do even their jobs. Bribery is accompanied by nepotism, rigging of elections, and other forms of financial fraud, with varieties of deceits in religious centres. Thus even though African countries attained political independence, structural injustice remained in vogue, perpetuated by African elites. Davidson is correct:

The point is to emphasise that the extraction of wealth from an already impoverished Africa was in no way halted by the 'transfer of power'. A transfer of poverty continued as before, even while the means of transfer were modified or camouflaged. (Davidson 1992:219)

As many peoples are becoming Christians and Muslims in Africa and as religion is very important for Africans, in the light of Africa's own fallacies of leadership and corruption mentioned above, can religion reorient Africa's sense of the common good and restore integral development? Also can Christianity and African indigenous cosmology help reorient African's theological anthropology away from the colonialist and Western hegemonic development paradigm based on social evolutionism that places Africa at the margins of development? These are the concerns of the next section of this article.

\section{Christian anthropology and development discourse}

One of the reasons Africans are converting to Christianity in droves is the strong relationship of Christian anthropology to African traditional anthropology. Christian anthropology is the Christian definition of what 'being human' means in the light of revelation. Following Augustine of Hippo, Christian anthropology can be summed up as desiring God in Christ above all else. Susan Ross (2012:5) captures this well: 'A Christian theological anthropology has Christ as its center - a Christ who desires to be with his friends, a God who desires that there be a world in which God's glory can be revealed'. Traditional African anthropology is the African thought of what it means to be human. It is drawn from African religiocultural values which reserve an important place for human life it reveres as sacred. In spite of differences in social stratifications, African cultures insist on respect for fellow human beings, including strangers. For this reason, wealth is communal in the sense that a wealthy person is assessed based on their contribution to the common good. Every person is created by God, and after a good life, one is committed to one's ancestors and remains a member of human community (Maimela 1991:4-14). Underlying African traditional anthropology is relatedness: that humans are 
called to relationship with one another, to contribute to the well-being of one another, to coexist in society and to have fulfilled lives within the context of peace in society through their interactions with one another. African anthropology segues to African ethics of Ubuntu - the African value of contributing to the well-being of others and of community.

In spite of the different ways various Christian traditions and denominations nuance it, Christian anthropology is based on the belief that human beings are created in the image and likeness of God. ${ }^{9}$ This means that each person, irrespective of race, gender, mental capacity or achievement, is created 'as a conscious, mindful, free and moral personality' (Slavcheva 2011:115). Every human being has inherent dignity that is not conferred by any authority but is already embedded naturally by God the creator. Being created in God's image, Glen Hughes (2011:1) explains, underscores 'the Christian idea of the human being as a person gifted with an inalienable dignity through her created participation in the freedom and self-determination of a transcendent God'.

The emphasis on inherent human dignity confirms the inviolability of this dignity in the face of viewpoints which instead base human dignity on achievement. To be human is to be a person. Personhood implies freedom and responsibility. It presupposes that opportunities would be created to enable each human person to actualise the inherent potentialities constitutive of personhood. It imposes on other persons the duty of mutual respect and serves as a deterrent to acts that would dehumanise others or take advantage of human vulnerability. Inherent human dignity entitles every person the right to justice through the rule of law. It is the basis upon which one remains innocent until proven guilty. It negates all forms of discrimination or segregation based on accidents of birth and circumstances of life. Human dignity belongs essentially to what it means to be human.

The Universal Declaration of Human Rights draws from this notion of human dignity. The declaration aimed at avoiding a future occurrence of the Nazi genocide perpetuated on the basis of ethnic and racial superiority. Such a viewpoint created not only the atrocities of the Nazi camps but also underlies the inhumanity of centuries of trans-Atlantic slave trade, the (1885) Berlin Conference Partition of Africa, foreign occupation and annexation of African land and resources, and the subsequent forceful administration of these territories for the benefit of various foreign powers, including the segregationist Apartheid Regime of South Africa that only ended in 1994. Christian anthropology equally emphasises interrelatedness as members of the human community. This 'belongingness' imposes upon all humans, the responsibility of promoting the common good and ensuring the well-being

9.See Genesis $1: 26-27$. It is important to point out that it is primarily stated in Christian theological anthropology that human beings are integrally constituted of body and soul. Humans are made to live together in society and to promote the body and soul. Humans are made to live together in society and to promote the common good essential for the continued survival of society and general wellbeing of humans. This is the prelude to resurrection, which is the end of humans created in the image and likeness of God who sustain them by giving them everlasting life. The human contribution to this is mutual coexistence in society. Humans are communicating creatures. God created woman to be a helpmate to Adam, so that they communicate with each other and with God (cf. Barnard 1972:254-270; Klug 1984:141-152). of the community. The story of Creation in Scripture emphasises not just the one man, but also the community of humans. The incarnation is meaningful not just because Jesus is God, but because he is the God-Man, taking flesh among humans, not only for the purpose of divinising humans but also to promote their interaction in the language of love, promoting mutual coexistence and assistance.

Christian revelation makes sense when the gospel message is correlated to the practical wisdom of the species homo sapiens. Humans must belong together in order to survive, and incorporate not only species of one's own kind, kith and kin, but strangers, gentiles, and humanity as a whole. As Martin Luther King Jr. rightly observed in his Christmas Sermon on Peace, in 1967:

This is the way our universe is structured; this is its interrelated quality. We are not going to have peace on Earth until we recognise this basic fact of the interrelated structure of all reality. (King 1967)

King's statement was made within the context of globalisation and its interrelatedness and mutual dependence of humankind for survival on earth.

Christian anthropology necessitates solidarity as the imperative value for humans irrespective of differences in language, lineage and multiplicity of religions. The ideal of Christian love from the 'Magna Carta of Christian life' - the beatitudes from Jesus' Sermon on the Mount (Mt. 5-7) implies that Christian revelation envisions a world where humans function as one another's keeper. Gaudium et Spes (nos. 24-32) of the Second Vatican Council specifies this, insisting that being created in God's image is indicative that God's plan gives human vocation a communitarian nature. This implies among other things that human beings are interdependent on one another (GS. 25), must promote the common good (GS. 26), and must revere the human person above all else (GS. 27) including loving and respecting one's enemies (GS. 28). Furthermore, Christian anthropology lays out the essential equality of human beings and the need to promote social justice (GS. 29). For this reason, a merely individualistic ethic will not do. On the contrary, all humans have the responsibility to create conditions favourable for every human being to live an optimum life with opportunities to actualise their potentialities. Being human always demands fidelity to human solidarity. Gaudium et Spes 32 states: 'God did not create man for life in isolation, but for the formation of social unity' (Abbott 1966:230).

In a discussion of the problems within the neoliberal capitalist agenda for globalisation, John Paul II (1999:no 55) called for 'globalisation of solidarity'. This means global mutual sharing and commitment for the improvement of the human condition. The theme of solidarity sums up the Christian revelation's notion of the human being as created in the image and likeness of God, implying the common origin of human beings and the imperative of love arising from this. Gerald J. Beyer's (2014:7-25) work on solidarity, especially from the perspective of John Paul II, interprets this theme as 
central to Catholic social thought. Solidarity not only explains the basis of humans as created in God's image, it underscores human interdependence, equality, respect, dignity, and God's expectation of humans to fulfil their obligation to one another as members of the human family.

According to Beyer, humanity must join hands to combat the culture of consumerism and love of power by which corporations enslave human beings for the purpose of profit. Solidarity calls for concerted effort to promote sustainable development conscious of generations of humanity who would inhabit the earth after our present generation. Christians are called to take seriously the implications of revelation in terms not only of mutual dependence but also on the need to image God, who loves and promotes life and wants it to be protected in all its ramifications. It is a call for integral salvation: Christianity does not devote itself to a pursuit of truth that neglects of the practical aspects of the socio-economic, political and cultural values of society on the human person. It recognises that what happens in one part of the globe affects other parts as well. A 'globalisation of solidarity' makes it imperative for humans to develop an economy that prioritises persons and not profit (Padilla 2014:69-90).

Within this construct it is not difficult to decipher the role Christian anthropology could play in bridging the gap between the rich and the poor. I agree with Daniel G. Groody (2008) that:

Theological anthropology helps us construct an alternative vision of human life that differs significantly from a market system that gives primacy to the economic and consumer agendas of globalisation often at the expense of human values. Amidst widespread cultural, economic, and social upheaval, theological anthropology also offers us an invaluable hermeneutical perspective that helps us understand the relational foundation of our existence, particularly as it unfolds through our relationships with God, ourselves, others, and the environment. (p. 252)

Because neoliberalism's operational anthropology is primarily mechanistic and hence materialistic, it is basically profit-oriented (not people directed), individualistic (prizing self-interest over the common good), and centres freedom within the bounds of the market. It adopts the social evolutionistic idea of infinite progress, which gives the rich and the dominant class opportunities to progress limitlessly, because those at the lower ladder of social evolution are meant to serve and provide labour for the developed progressive peoples. It therefore negates the thrust of Christian anthropology which emphasises equality of humans created in the image and likeness of God.

On the theme of solidarity, Rowan Williams, the former Archbishop of Canterbury, argues that theological anthropology contributes positively to economics by critiquing the exclusive consideration of economics outside the confines of human activity and interaction. For Williams (2010:611), we have to think of one another as 'equally helpless alone and gifted in relationship'. In other words, humanity both rich and poor has something to contribute to the mutual societal existence, or else our life will be less than wholesome. 'It [theological anthropology] proposes a model of human life together that insists on the fact that we are all involved in the fate of any individual or group and that no one is exempted from damage or incapable of gift within the human community as God intends it'. Secondly, Christian theological vision provides a notion of human personality from the point of view of virtue, as a guide to economic life and human life as a whole. This way, theological anthropology questions our assumptions of human motivation and what is rewarded and what is not in economic activity and how these affect societal life and values, building and raising family, promoting human well-being and standing for the good of the human person as a whole. Just like every other human activity, theological anthropology must be the yardstick for judging economic activity morally according to how it advances or not the basic humanum constitutive of persons as imago Dei and not as homo economicus. Williams (2010) asserts:

It [theological anthropology] recalls us to the idea that what makes humanity human is completely independent of anyone's judgements of failure or success, profit or loss. It is sheer gift, sheer love, in Christian terms. And if the universe itself is founded on this, there will be no sustainable human society for long if this goes unrecognised. (p. 615)

\section{Inculturating Christian anthropology in Africa}

In addition to the emphasis on other aspects of theology biblical hermeneutics, systematics, liberation, liturgy, etc., inculturation theology should integrate traditional African anthropology summed in the African philosophy of 'live and let live', Ubuntu, into Christian anthropology. Ubuntu (meaning humanism or humaneness) is a whole complex of behaviour, character, and integrity by which Africans express commonality and purpose in life. It emphasises protection of human dignity and obligation to promote the common good of the community. It recognises the personhood of all human beings and accords respect to others as fellow human beings on account of the common humanity of all persons (Mnyaka \& Motlhabi 2005). Ubuntu is behaving according to human nature; it is a form of being human that befits a human being. It is an inclination to the good, one that bears witness to the good and challenges others to do the good for its own sake. It expresses human belongingness to one another and the mutual cooperation necessary for harmonious social existence. Ubuntu thus guards against the selfishness and individualism that corrupts Africa's political, social, religious and economic structure. Ubuntu expresses the human interconnectedness at the heart of Christian anthropology. It holds that humans are children of one God and therefore are brothers and sisters. For this reason, it is in the best interest of human beings to protect one another, the rich and the poor. The principles of Catholic social teaching: solidarity, subsidiarity, common good and human dignity are expressed in the African concept of Ubuntu. 
The corruption by which African leaders under-develop Africa negates the communal nature of Ubuntu. Secularisation of traditional values, thirst for power and wealth, timidity and inferiority complex, desire to be like the colonial masters, colonial capitalism, the misconception of civil service as the white man's job, jointly contributed to endemic corruption in Africa (Murove 2005). For this reason, inculturation of Ubuntu as African Christian anthropology should be done by imbuing in African leaders and business entrepreneurs the idea of the common humanity they share with other citizens in their countries and the common good all humans ought to promote. Theology of inculturation therefore ought to bring to the fore in Africa, the continuing relevance of the spirit of solidarity imbedded in Ubuntu in order to counter the selfishness and excessive individualism introduced into African countries by various external agents.

African Christian leaders jointly must be involved in the reconstruction of Africa by patterning with various African governments and non-governmental organisations towards promoting democracy and good governance, the rule of law and constitutional reform, and economic and social changes to uplift African standards of living. In postcolonial postindependent Africa, liberative theologies must ensure through constant participation (as well as exhortations of government and church leaders) that nobody is left in deplorable conditions. Particular mention must be made of the New Partnership for Africa's Development (NEPAD) by which African leaders and governments have hoped to engage in the reconstruction of Africa. NEPAD as the African Union's strategic network for African development in the 21st century addresses critical challenges facing the continent: poverty, development and Africa's marginalisation internationally. Importantly, however, its focus also includes issues of agriculture and food security, climate change and natural resource management, regional integration and infrastructure, human development, economic and corporate governance, and cross-cutting issues such as gender, capacity development and ICT.

Even though formally declared in 2001, NEPAD continues the vision of the foremost African leader Kwame Nkrumah of Ghana who had advocated for a united Africa to overcome the challenges posed by colonialism and neocolonialism. The implementation of NEPAD is a responsibility not only for African leaders but also for African Christian theologians and indeed for all people of goodwill. Various religious organisations like Christian and Muslim Faith based organisations are already engaged with non-governmental organisations in promoting justice, reducing hunger, provision of infrastructures, building hospitals, schools, engaging in various forms of advocacy for the poor, being the voice for the voiceless in African countries (Ogbonnaya 2012:10). Just as Pope Benedict XVI's Apostolic Exhortation of the Second African Synod Africae Munus (2009:nos 20, 21, $23,79)$ recommends, in order to stem the tide of the African anthropological crisis which cuts across all aspects of African life, and to promote sustainable development in
Africa, African theology and church leaders must take its prophetic function seriously in order to ensure there is growth with development in Africa. Christian anthropology in Africa must inculturate Ubuntu so as to restore the African holistic idea of development intrinsic to the African integral world view.

\section{Conclusion}

Even though Africa is marginalised in international trade and looked down upon because of the social evolutionism that undergirds world trade and international relations, Christian anthropology has the potential to humanise globalisation by putting into practice a globalisation of solidarity arising from human interdependence. African countries must liberate themselves from their prevailing crisis of identity preventing them from making optimum use of their resources for their own development. African Christian theology can contribute to Africa's liberation and development by proffering measures towards implementing the virtues of Ubuntu into Africa's economic, political, social and educational structures. This could help heal Africa's anthropological poverty, help reconstruct Africa and put the continent and its peoples in the path to holistic development, one that is integral catering for the vital, social, cultural, religious and personal values of Africans.

\section{Acknowledgements Competing interests}

The author declares that he has no financial or personal relationships which may have inappropriately influenced him in writing this article.

\section{References}

Abbott, W.M., 1966, The documents of Vatican II, Guild Press, New York.

Ake, C., 1996, Democracy and development in Africa, Brooklings Institution Press, Washington D.C.

Barnard, L.W., 1972, 'The Father of Christian anthropology', Zeitschrift für die Neutestamentliche Wissenschaft und die Kunde der älteren Kirche 63(3-4), 254-270.

Benedict XVI, 2009, Post-Synodal Apostolic Exhortation Africae Munus, viewed 4 November 2015, from http://w2.vatican.va/content/benedictxvi/en/apost exhortations/documents/hf_ben-xvi_exh_20111119_africae-munus.html

Beyer, G.J., 2014, 'The meaning of solidarity in Catholic social teaching', Political Theology 15(1), 7-25. Viewed 20 June 2015 from http://dx.doi.org/10.1179/1462 317X13Z.00000000059

Braedley, S. \& Luxton, M. (eds.), 2010, Neoliberalism and everyday life, McGillQueen's University Press, Montreal, QC.

Chomsky, N., 1999, Profit over people: Neoliberalism \& global order, Seven Stories Press, New York.

Commission Française Justice et Paix, 1978, 'New international economic order and the Church', AFER 20(3), 186-189.

Davidson, B., 1969, The African genius: An introduction to African social and cultural history, Little, Brown and Company, Boston, MA.

Davidson, B., 1992, The black man's burden: Africa and the curse of the nation-state, Times Books, Random House, New York.

French, H., 2012, 'Seven of the world's 10 fastest-growing economies are African', Business Insider, viewed 14 February 2016, from http://www.businessinsider. com/seven-of-the-worlds-10-fastest-growing-economies-are-african-2012-5

Global Monitoring Report, 2015, Development goals in an era of demographic change-16, viewed 14 February 2016 from http://pubdocs.worldbank.org/ change-16, viewed 14 February 2016 from http://pubdocs.Worldbank.org/
pubdocs/publicdoc/2015/10/503001444058224597/Global-MonitoringReport-2015.pdf

Groody, D.G., 2008, 'Globalising solidarity: Christian anthropology and the challenge of human liberation', Theological Studies 69(2), 250-268. http://dx.doi. org/10.1177/004056390806900201 
Harry, S., Truman library and Museum, Truman's Inaugural Address, 20 January 1949, viewed 4 March 2016, from http://www.trumanlibrary.org/whistlestop/50yr archive/inagural20jan1949.htm

Haslam, P.A., Schafer, J. \& Beaudet, P. (eds.), 2009, Introduction to international development: Approaches, actors and issues, Oxford University Press, Oxford.

Hughes, G., 2011 'The concept of dignity in the universal declaration of human rights', Journal of Religious Ethics 39 (1), 1-24. http://dx.doi.org/10.1111/j.1467-9795. 2010.00463.x

International Bank for Reconstruction and Development/The World Bank, 2016 Poverty in a rising Africa: Africa poverty report, viewed 20 May 2016, from http:// www.un.org/africarenewal/sites/www.un.org.africarenewal/files/Poverty $\% 20$ in $\% 20 a \% 20$ Rising $\% 20$ Africa $\% 200$ verview.pdf

International Documentation Center, 1976, 'Towards a new international economic order', IDOC Bulletin 47, 15-20.

Jerven, M., 2013, Poor numbers: How we are misled by African development statistics and what to do about it, Cornell University Press, Ithaca, NY.

J.O'S, 2013, 'Development in Africa: Growth and other good things', The Economist, viewed from http://www.economist.com/blogs/baobab/2013/05/developmentafrica

John Paul II, 1999, Ecclesia in America, United States Catholic Conference, Washington, DC

Kim, J.Y. \& Christine, L., 2016, 'Foreword', in World Bank Group, Global Monitoring Report 2015/2016: Development goals in an era of demographic change, World Bank, Washington, DC. http://dx.doi.org/10.1596/978-1-4648-0669-8, viewed 03/14/2016 from https://openknowledge.worldbank.org/

Kim, S., 2008, 'Editorial: [Millennium Development Goals and public theology]', International Journal of Public Theology 2(2), 139-143.

King, M.L., Jr., 1967, A Christmas Sermon on peace, viewed 5 May 2016 from http:// www.ecoflourish.com/Primers/education/Christmas_Sermon.html

Klein, N., 2008, The shock doctrine: The rise of disaster capitalism, Penguin Books, New York.

Klug, E., 1984, 'The doctrine of man: Christian anthropology', Concordia Theological Quarterly 48(2-3), 141-152.

Leke, A., Lund, S., Roxburgh, C. \& Van Wamelen, A., 2010, 'What's driving Africa's growth', viewed 20 January 2015 from http://www.mckinsey.com/insights/ economic_studies/whats_driving_africas_growth

Lewis, S., 2005, Race against time, House of Anansi Press Inc., Toronto, ON.

Maimela, S.S., 1991, 'Traditional African anthropology and Christian theology', Journa of Theology for Southern Africa 76, 4-14.

McKinsey Global Institute, 2010, 'Lions on the move: The progress and potential of African economies', viewed 14 July 2016 from http://www.mckinsey.com/globalthemes/middle-east-and-africa/lions-on-the-move

McMichael, P., 2008, Development and social change, Pine Forge Press, Los Angeles, CA.

Mnyaka, M. \& Motlhabi, M., 2005, 'The African concept of Ubuntu/Botho and its socio-moral significance', Black Theology 3(2), 215-237.

Mudimbe, V.Y., 1988, The invention of Africa: Gnosis, philosophy, and the order of knowledge, Indiana University Press, Bloomington, IL.

Murove, F.M., 2005, 'African bioethics: An exploratory discourse', Journal for the Study of Religion, 18(1), 16-36.

Nyerere, J.K., 1993 'Foreword', in The South Centre, facing the challenge: Responses to the report of the South Commission, edited by Gale Raj, Zed Books, London, xiv- $\mathrm{x}$.

Ogbonnaya, J., 2012, 'Religion and sustainable development in Africa: The case of Nigeria', International Journal of African Catholicism 3(2), 1-22.

Ogbonnaya, J., 2013, Lonergan social transformation and sustainable human development, Pickwick Publications, Kindle Edition, Eugene, OR.
Organisation of African Unity, 1980, Lagos plan of action for the economic development of Africa 1980-2000, viewed 20 August 2016 from www.merit.unu.edu/wpof Africa 1980-2000, viewed 20 August 2016 from
content/uploads/2015/01/Lagos-Plan-of-Action.pdf

Padilla, C.R., 2014, 'The globalisation of solidarity', Journal of Latin American Theology 9(2) 69-90.

Peet, R. \& Hartwick, E., 2009, Theories of development: Contentions, arguments, alternatives, The Guilford Press, New York.

Piketty, T., 2014, Capital in the twenty-first century, transl. A. Goldhammer, The Bellnap Press of Harvard University Press, Cambridge, MA

Rist, G., 2002, The history of development: From Western origins to global faith, transl. P. Camiller, Zed Books, London.

Rodney, W., 1972, How Europe underdeveloped Africa, Bogle-L'Ouverture Publications, London.

Ross, S., 2012, Anthropology: Seeking light and beauty, Liturgical Press, Collegeville, MN.

Rostow, W.W., 1991, The stages of economic growth: A non-communist manifesto, Cambridge University Press, Cambridge, MA.

Salomon, M.E., 2013, 'From NEIO to now and the unfinishable story of economic justice', International and Comparative Law Quarterly 62(1), 31-54. http://dx.doi org/10.1017/S0020589312000590

Sharma, P., 2013, 'The United States, the World Bank, and the challenges of international development in the 1970s', Diplomatic History 37(3), 572-604. http://dx.doi.org/10.1093/dh/dht024

Slavcheva, K., 2011, 'Human rights, dignity and freedom: An orthodox perspective', Baptistic Theologies 3(2), 115-123.

Stiglitz, J.E., 2002, Globalisation and its discontents, W.W. Norton and Company, New York.

The Economist, 2013, 'The economist explains itself: Why are the economist writers anonymous', The Economist, 4 September, viewed 9 September 2016 from http:// www.economist.com/blogs/economist-explains/2013/09/economist-explainsitself-1

The South Commission, 1990, The challenge to the South: The report of the South Commission, Oxford University Press, Oxford.

The World Bank, 2015a, Annual report, viewed from http://www.worldbank.org/en/ about/annual-report/regions/afr

The World Bank, 2015b, 'Speech by World Bank Group President Jim Yong Kim at the Global Launch of "Poverty in a rising Africa" report', viewed 20 August 2016 from http://www.worldbank.org/en/news/speech/2015/10/16/speech-world-bankgroup-president-jim-yong-kim-global-launch-poverty-rising-africa-report

The World Bank Annual Report, 2011, viewed 9 September 2016 from http://wwwwds.worldbank.org/external/default/WDSContentServer/WDSP/IB/2011/09/09/ $00035616120110909023530 /$ Rendered/PDF/644400PUBOYearOlOversionOBOX3 61537B.pdf

United Nations, 2015, The Millennium Development Goals report 2015, viewed 7 July 2016 from http://www.un.org/millenniumgoals/2015 MDG Report/pdf/ MDG\%202015\%20rev\%20\%28July\%201\%29.pdf

United Nations Economic Commission for Africa, 1990, African alternative framework to structural adjustment programs for socio-economic recovery and transformation (AAF-SAP), Addis Ababa, viewed 15 August 2016 from http://hdl. handle.net/10855/5670

Williams, R., 2010, 'Theology and economics: Two different worlds?', Anglican Theological Review 92(4), 607-615.

World Council of Churches, 1975, 'New international economic order and the churches', The Ecumenical Review 27(4), 402-404.

World Economic Forum, 2016, 'Is Africa winning the battle against corruption?', viewed 9 September 2016 from https://www.weforum.org/agenda/2016/01/isafrica-winning-the-battle-against-corruption/ 